\title{
TOUR GUIDE'S COMPETENCIES AS PREDICTORS OF TOURISTS' SUSTAINABLE BEHAVIOR - EVIDENCE FROM NATIONAL PARKS
}

\author{
Dunja DEMIROVIĆ BAJRAMI* \\ Geographical Institute "Jovan Cvijić", Serbian Academy of Sciences and Arts, 9 Djure Jaksica, 11000 Belgrade, Serbia and South Ural State \\ University, Institute of Sports, Tourism and Service, 76 Lenin Ave, 454080 Chelyabinsk, Russian Federation, e-mail: d.demirovic@gi.sanu.ac.rs
}

Tatiana N. TRETIAKOVA

South Ural State University, Institute of Sports, Tourism and Service, Department of Tourism and Socio-Cultural Services, 76 Lenin Ave, 454080 Chelyabinsk, Russian Federation, e-mail: ttn1@ mail.ru

Yulia A. SYROMIATNIKOVA

South Ural State University, Institute of Sports, Tourism and Service, Department of Tourism and Socio-Cultural Services, 76 Lenin Ave, 454080 Chelyabinsk, Russian Federation, e-mail: syromiatnikovaya @ susu.ru

Marko D. PETROVIĆ

Geographical Institute "Jovan Cvijić", Serbian Academy of Sciences and Arts, 9 Djure Jaksica, 11000 Belgrade, Serbia and South Ural State University, Institute of Sports, Tourism and Service, 76 Lenin Ave, 454080 Chelyabinsk, Russian Federation, e-mail: m.petrovic@ gi.sanu.ac.rs

\section{Milan M. RADOVANOVIĆ}

Geographical Institute "Jovan Cvijić", Serbian Academy of Sciences and Arts, 9 Djure Jaksica, 11000 Belgrade, Serbia and South Ural State University, Institute of Sports, Tourism and Service, 76 Lenin Ave, 454080 Chelyabinsk, Russian Federation, e-mail: m.radovanovic@gi.sanu.ac.rs

\begin{abstract}
Citation: Demirović Bajrami, D., Tretiakova, T.N., Syromiatnikova, Y.A., Petrović, M.D., \& Radovanović, M.M. (2020). TOUR GUIDE'S COMPETENCIES AS PREDICTORS OF TOURISTS' SUSTAINABLE BEHAVIOR - EVIDENCE FROM NATIONAL PARKS. GeoJournal of Tourism and Geosites, 32(4), 1277-1282. https://doi.org/10.30892/gtg.32413-569
\end{abstract}

\begin{abstract}
The aim of the study was to identify which tour guide's competencies can be predictors of environmentally sustainable behavior of visitors of national parks. Authors gathered answers through questionnaires from 305 visitors of two national parks located in Serbia. The results showed that guide's knowledge and telling stories in an engaging and interesting way were predictors for almost all learning outcomes. Also, guides who are energetic and show that they enjoy doing their job, can arouse visitors' interest in the presented topic, create pleasant memories and serve as a role model for sustainable behavior after the tour ends.
\end{abstract}

Key words: national parks, tour guide's competencies, sustainable behavior, visitors, learning outcomes, Serbia

\section{INTRODUCTION}

According to existing studies, tour guides are expected to perform a wide range of roles in facilitating the tourist experience. Tour guiding may be complex and it often varies depending on the environment, topic and type of a conducted tour (Hansen and Mossberg, 2017). The quality of the tour guide service has great impact on tourist satisfaction and destination loyalty (Kuo et al., 2018; Hwang and Lee, 2019), and on destination image and branding (Pereira, 2015), but the impact will be positive only if visitors' expectations are matched with guide's services. Studies examining the guide from the perspective of the customer or tourist, included examining tour guides' roles (Haig and McIntyre, 2002; Yu et al., 2002; Weiler and Yu, 2007), tour guide performances (Zhang and Chow, 2004), tourist satisfaction with tour guide services (Wong, 2001), tour guide administration system (Dong et al., 2002) and message delivered to tourists (Armstrong and Weiler, 2002).

Tour guide's competencies have a great impact on what feelings and knowledge visitors will develop after the tour ends. Guide's enthusiasm and passion were marked as initial in fulfilling different roles (Bryon, 2012), while professional skills can have impact on all involved parties. Enough knowledge on the topic being presented, practical experience of the guide and personal qualities pro ved to have positive effects on a person, some part of history or local community and attractiveness of tourism facility (Tsai et al., 2016). Also, professional skills like knowing how to meet visitor's needs and professional attitudes lead to a developing of closer relati onship between guide and visitors/tourists (Hwang and Lee, 2019). Tourists who seek the services of a tour guide usually do that because they want to be guided by an expert and that moment tour guides should use to teach tourists how to behave properly, to increase their knowle dge and skills (Koroglu and Guzel, 2013), all of this because people "look for memorable consumption experiences that can affect them for a long time and might even change them" (Mossberg, 2003, pp. 59).

Weiler and Walker (2014) stated that the tour guides role is more and more connected with sustainability issues and that tours should contribute to changing visitors' behavior and conservation perspectives not just on destination that they are visiting, but also in their everyday situations. During tours, guides strive to increase tourists' knowledge about the visited destination and create special empathy towards local people, their culture and environment (Black and Crabtree, 2007) or to promote responsible behavior by modifying or by pointing to those which are not appropriate (Hu and Wall, 2012). In research done by Matsushima (2007), visitors of the public beaches in Japan became more aware of environmental problems and consequences of visitors' depreciative behaviors after the tour guide presented them how those beaches can be protected and what every visitor can do to save the environment. Also, Wiles and Hall (2005) proved that tourists can change their attitudes by highlighting that interpretation tour in some national parks in the USA lead to different perspectives when it comes to wildland fire. These researches showed that increasing tourists' knowledge, creating positive feelings for the environment

\footnotetext{
* Corresponding author
} 
or trying to change their values can contribute to sustainable behavior of visitors. Encouraging visitors to minimize their negative impact on environment during traveling has become one of the priorities in developing sustainable tourism and this is especially pronounced in national parks and other natural protected areas where the environment is fragile (Brown et al., 2010), while education of the tourists during visits was seen as desirable strategy to achieve that goal (Marion and Reid, 2007). Boren et al. (2009) and Curtin (2010) highlighted that managers and, especially, tour leaders can modify visitors' behavior in areas with wildlife by giving them instructions and supervision, that is, by teaching them how their behavior can be with low impact (for example, decreasing noise and disturbance, feeding animals where permitted).

This showed that the tour guide has unique opportunity to, in direct contact with tourists, increase visitors' knowledge, understanding and provide memorable and meaningful experience (Pereira and Mykletun, 2012), while the guide's knowledge and skills are important competencies in encouraging environmentally responsible behavior (Tatar et al., 2018). National parks can play a critical role in moving the communities and visitors they serve towards a more sustainable future. Generally, national parks have a positive impact on society and their main challenge is to ensure that they deliver social benefits in ways that are environmentally and economically sustainable. To thrive sustainably, national parks must have access to all the skills and knowledge they need. They need to become better at using the skills and knowledge of their staff, especially tour guides. By guides' behavior, national parks could become demonstration models for a sustainable society. Since visitors in national parks have direct contact with tour guides, the question is whether and how the tour guide can influence social desirable development and behavior of visitors. The aim of the study is to identify which tour guide's competencies can be predictors of environmentally sustainable behavior of visitors of national parks which will be applicable in their everyday situations. As a case study, authors gathered answers from visitors of the two national parks located in the Republic of Serbia.

\section{MATERIAL AND METHODS}

Visitors' perceptions of the tour guide's competencies were examined in regard to the four categories: 1) handling the group within the national park (14 variables), 2) communication skills (7 variables), 3) knowledge and pedagogy (14 variables), and 4) professionalism (9 variables; variable - Cooperation with teachers - was excluded from the questionnaire since it was not relevant for the research). The four groups of competencies were drawn from the research done by: Pereira (2015), Al Jahwari et al. (2016) and Schep et al. (2017). Visitors assessed tour guide's competencies using a five-point scale (1-totally disagree, 5 -totally agree).

A principal component factor analysis was applied to see if all competencies should be kept for further analysis. Hence, 44 tour guide competencies were analyzed by testing inter-correlations. The Bartlett's test of sphericity was statistically significant ( $p<0.001)$ and the Measure of Sampling Adequacy (KMO) was 0.831, while Cronbach's Alpha was 0.803. Four factors were identified with a total of 67.4\% variance explained (each factor had a reliability alpha over 0.7 ). Four variables within the fourth group (Professionalism) had to be excluded since their factor loadings were lower than 0.4. Those variables are: Cooperation with other guides, Reflecting on personal performance, Professional development, and Contribute to improving tours, leaving that the last factor contained 5 variables used for further analysis. It seems that these variables gained lower loadings because they cannot be easily evaluated by visitors (e.g. visitor cannot know if the guide used the opportunities for professional development offered by the national park or if the guide consulted other guides about the tour).

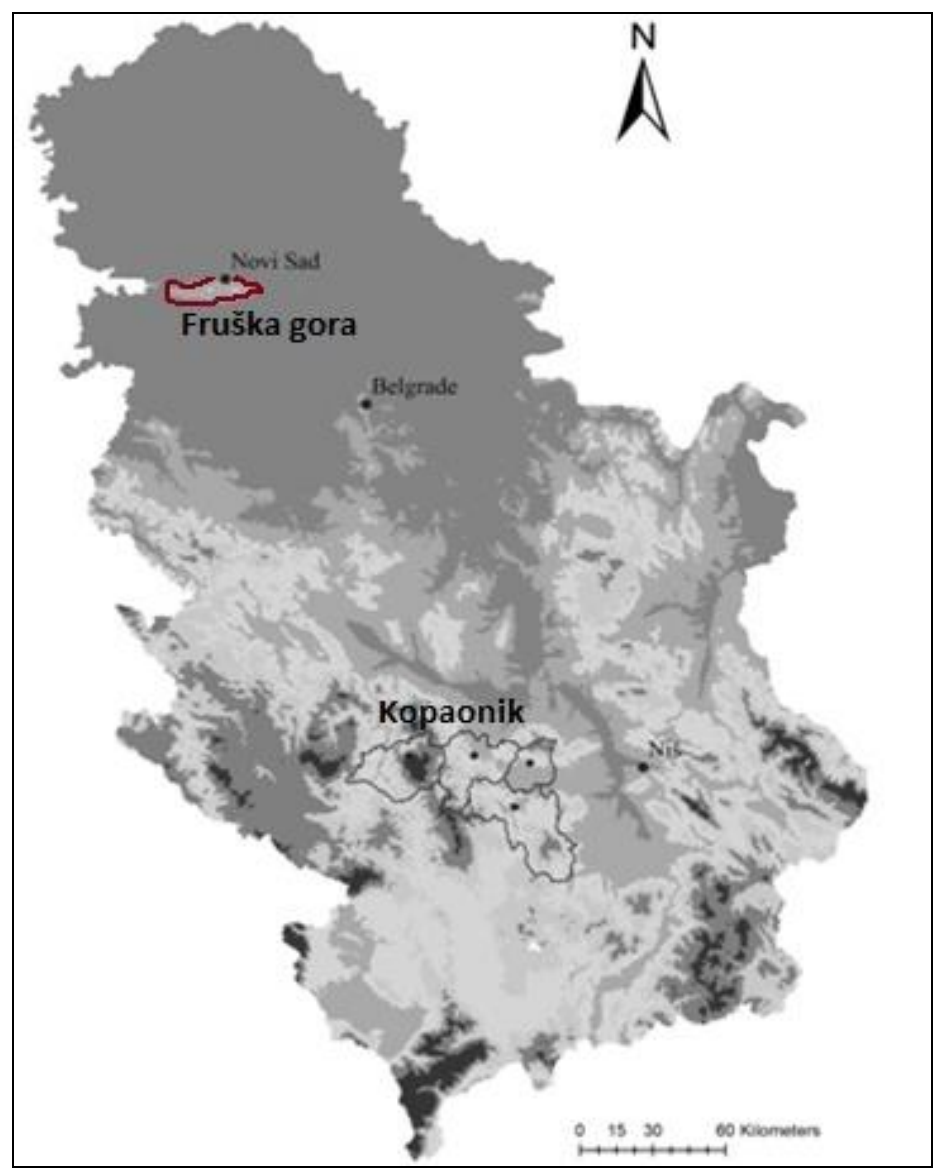

Figure 1. Location of the two national parks in Serbia (Fruška gora and Kopaonik) where the research was conducted

The four groups of learning outcomes were drawn from the outcomes for environmental education in national parks defined by Powell et al. (2020). These four groups of learning outcomes were: 1) enjoyment and satisfaction (4 variables), 2) interest/motivation to learn (4 variables), 
3) action orientations ( 7 variables), and 4) action (6 variables). Visitors of the national parks were asked to assess the extent to which they had learned different things during the guided tour through the parks using a five-point scale $(1$-totally disagree, 5 - totally agree).

The Republic of Serbia has five declared national parks that are managed by specialized public companies and whose business is regulated by the National Parks Act (Ćurčić et al., 2019). With the Act, activities that will not harm species and ecosystems were defined, all for the purpose to secure sustainable development. The first national park in Serbia was founded in 1960 (National park Fruška gora), while the youngest was declared in 1986 (National park Šar-planina). All national parks are part of the European Federation of National Park (EUROPARC). There is no precise data on the number of tour guides in Serbian national parks.

Collection of the field data was done by a face-to-face survey methodology. In two national parks in Serbia (Fruška gora and Kopaonik Figure 1), researchers were present during every guided tour and after the tour ended, adult visitors were asked to participate in the research. The fieldwork was carried out from June to September 2019 and, in total, 305 usable questionnaires were collected. Of the total number of the respondents, 51\% were male and $49 \%$ were female, ages between 31 and 40 (32\%) and 41 and 50 (30\%), employed (41\%) or unemployed (22\%), with a bachelor degree (56\%), visiting national park with a family member (42\%) or with a friend (34\%).

The profile of the respondents and descriptive analyses were done by using an SPSS Statistics Version 22.0 for Windows. The collinearity statistics were expressed through calculating tolerance and variation inflation factor (VIF) with the aim to measure the degree of correlation between predictor variables, while a stepwise model of the confirmatory regression analysis was used to define the range of the defined tour guide's competencies as predictors of learning outcomes in national parks.

\section{RESULTS}

In order to use space in the manuscript more efficient, values of the tolerance and variation inflation factor were not presented in the tables for each learning outcome, but they were in accordance with the recommendations of Coolican (2004), ranging from .465 to 1.000 for the values of tolerance, and between 1.000 and 2.160 for the VIF values.

\section{Predictors of enjoyment and satisfaction}

Table 1 shows that five tour guide's competencies can be marked as predictors for the first group of learning outcomes - enjoyment and satisfaction, while the regression model was strong and explained $47 \%$ of the variance. Creating a positive and relaxed atmosphere $(\beta=.436)$ and storytelling $(\beta=.422)$ were the strongest predictors of the enjoyment and satisfaction. Providing safety information before the tour starts was the third strongest predictor $(\beta=.361)$, showing that, in order to feel relaxed, visitors in national parks like to know which safety instruction they need to follow during the tour. Although the last two predictors gained slightly lower scores, they can still be considered important for the enjoyment and satisfaction. This showed that visitors' enjoyment and satisfaction will be increased if guides keep an overview of the group and make sure that all visitors are following the group $(\beta=.315)$ and if the guides are energetic and enthusiastic about the things they tell, and know how to kindle enthusiasm in the visitors during the tour.

Table 1. Regression model for enjoyment and satisfaction

\begin{tabular}{|c|c|c|c|c|c|}
\hline \multirow{2}{*}{ ENJOYMENT AND SATISFACTION } & $\begin{array}{ll}R \quad .597 \\
\end{array}$ & $R^{2} .475$ & Adjusted $R^{2} \quad .416$ & Std. error of estimate $\quad .744$ & \\
\hline & $R^{2}$ change .021 & F change 5.283 & $d f 1, d f 2 \quad 1,103$ & Sig. F change $\quad .039$ & \multirow{3}{*}{ Sig. } \\
\hline \multirow{2}{*}{ Predictors } & \multicolumn{2}{|c|}{ Unstandardized coefficients } & \multicolumn{2}{|c|}{ Standardized coefficients } & \\
\hline & $B$ & Std. error & $\mathrm{B}$ & $T$ & \\
\hline Storytelling & .452 & .159 & .422 & 4.266 & .001 \\
\hline Providing safety information before the tour & .401 & .137 & .361 & 3.631 & .019 \\
\hline 4) Keeping an overview & .363 & .114 & .315 & 3.086 & .028 \\
\hline
\end{tabular}

\section{Predictors of interest and motivation to learn}

The regression model for the learning outcome "interest and motivation to learn" contained four tour guide's competencies and explained $42 \%$ of the variance (Table 2 )

Table 2. Regression model for interest and motivation to learn

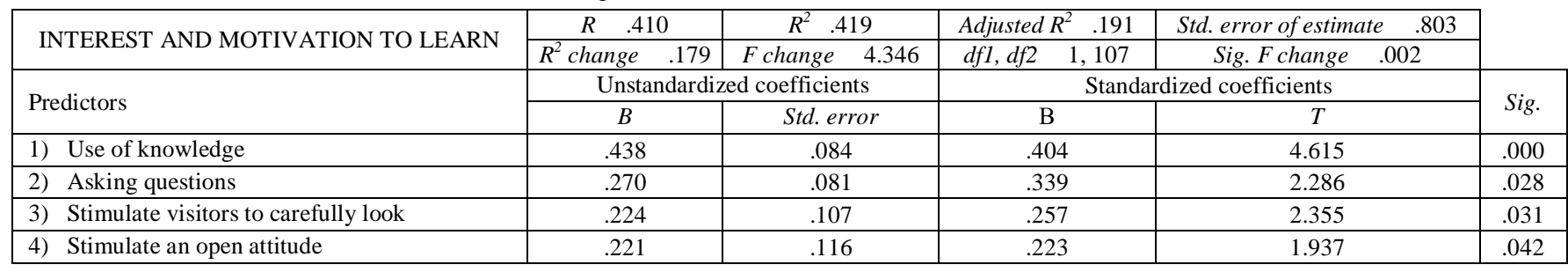

In order to increase interest and motivation of visitors to learn, tour guides need to have a wide knowledge about national park, different species, sustainable development, etc. and be capable to transfer that knowledge in an interesting way and in a way that visitors can understand $(\beta=.404)$. Also, asking questions $(\beta=.339)$ proved to be a strong predictor showing that questions can give visitors room for different perspectives, encourage them to think out loud, contextualize or use their imagination. Enable visitors to see some thing in person in national park (e.g. animal, plant) and inspire them to have an open attitude towards new experiences can boost visitors' interest to learn more after the tour ends. In sum, all predictors for this learning outcome belong to "knowledge and pedagogy" group of guide's competencies.

\section{Predictors of action orientations}

The regression model for the learning outcome "action orientations" was weaker than the last two models, since it explained only $31 \%$ of the variance (Table 3). Four tour guide's competencies can be marked as important predictors for gaining knowledge, developing some attitudes and skills. The guide's knowledge and the way it is presented to visitors $(\beta=.335)$ has the strongest impact on the third learning 
outcome. Finding enough balance between explaining and seeing things in real can ensure better experience for visitors $(\beta=.304)$, and visitors' active participation in a tour through asking questions, giving comments or own perspectives $(\beta=.258)$ can help them in developing sustainable behavior. Using some learning activities and exercises were appropriate can be important for the success of this learning outcome.

Table 3. Regression model for action orientations

\begin{tabular}{|c|c|c|c|c|c|}
\hline \multirow{2}{*}{ ACTION ORIENTATIONS } & $R \quad .462$ & $R^{2} \quad .307$ & Adjusted $R^{2} .350$ & Std. error of estimate & \\
\hline & $R^{2}$ change .035 & F change 5.418 & $d f 1, d f 2 \quad 1,109$ & Sig. F change $\quad .022$ & \\
\hline \multirow{2}{*}{ Predictors } & \multicolumn{2}{|c|}{ Unstandardized coefficients } & \multicolumn{2}{|c|}{ Standardized coefficients } & \multirow{2}{*}{ Sig. } \\
\hline & $B$ & Std. error & $B$ & $T$ & \\
\hline 1) Use of knowledge & .455 & .131 & .335 & 3.168 & .001 \\
\hline 2) Balance between interaction and explaining & .368 & .125 & .304 & 2.597 & .004 \\
\hline 3) Asking questions & .279 & .102 & .258 & 2.271 & .028 \\
\hline 4) Usage of learning activities & .242 & .093 & .217 & 2.135 & .012 \\
\hline
\end{tabular}

Predictors of action

The regression model for the last group of learning outcomes was strongly explained by five guide's competencies, since they explained $45 \%$ of the variance (Table 4 ).

Table 4. Regression model for action

\begin{tabular}{|c|c|c|c|c|c|}
\hline \multirow{2}{*}{ ACTION } & $\begin{array}{ll}R & .437 \\
\end{array}$ & $R^{2} \quad .446$ & Adjusted $R^{2} .382$ & Std. error of estimate $\quad .894$ & \\
\hline & $R^{2}$ change $\quad .036$ & F change 4.189 & $d f 1, d f 2 \quad 1,108$ & Sig. F change .042 & \\
\hline \multirow{2}{*}{ Predictors } & \multicolumn{2}{|c|}{ Unstandardized coefficients } & \multicolumn{2}{|c|}{ Standardized coefficients } & \multirow{2}{*}{ Sig. } \\
\hline & $B$ & Std. error & $B$ & $T$ & \\
\hline 2) Using objects for critical analyses & .432 & .109 & .367 & 3.353 & .000 \\
\hline 3) Storytelling & .420 & .114 & .288 & 3.102 & 0.03 \\
\hline 4) Asking questions & .316 & .103 & .245 & 2.569 & 0.02 \\
\hline
\end{tabular}

Encouraging visitors to behave sustainably on their next trip or in everyday situations and to do something new depends on guide's knowledge $(\beta=.392)$ and his/her ability to give clear examples by critically analyzing how visitors' behavior or activities can potentially have negative impact on species in national parks $(\beta=.367)$. Telling stories in an engaging way $(\beta=.288)$ and letting visitors to actively participate in a tour by asking questions $(\beta=.245)$ were significant predictors. The results showed that being enthusiastic and energetic during the tour can encourage visitors to take some actions or behave the same way when the tour is over.

\section{DISCUSSION AND CONCLUSION}

The results of the research showed that tour guide's competencies which belong to two groups - "handling the group within the national park" and "knowledge and pedagogy" were important predictors for the learning outcomes of visitors in national parks, i.e. have significant impact on shaping tourists' sustainable behavior.

The guide's ability to create a relaxed and positive atmosphere, for example, by using humor can have a positive impact on visitors to feel relaxed and can have impact on their enjoyment. As Hamalainen and Vahasantanen (2011) showed in their research, making atmosphere relaxed can encourage people to learn more, while pleasant environment is stimulating for visitors' satisfaction (Etelapelto and Lahti, 2008). The results indicated that introducing visitors to the safety instructions in national park can relax them before the tour starts. Visitors sometimes have a perception of national parks as wild and unpredictable environment, so knowing how to behave and what to expect during the tour can calm them and prepare better for the tour. It is proven that negative perception of risk and safety during vacation can have negative impact on destination image, choice and visiting the same destination again (Siew et al., 2018). Clear safety instructions like staying on the trails during the tour, staying away from the animals, do not leave food or garbage, indicating that there will be special and safe places to take pictures, should not be used to intimidate visitors, but rather presented as something that can have double benefit - prevent visitors' injuries and keep them safe, but also, that it will protect the park from degradation.

For the feeling of visitors' enjoyment, tour guides need to keep an overview of the group and make sure that all visitors are following the group. Tour guides should take the lead, but try to do that without putting themselves above the group. Also, all of this can make visitors to feel safe. If a tour guide is energetic and enthusiastic about the things he/she tells and knows how to convey that enthusiasm to visitors, it will affect enjoyment, and what is more important, it can have positive impact on visitors' actions after the tour ends. Some previous research highlighted that guide's enthusiasm had great impact on visitors' satisfaction with the provided service and the tour in general, while those guides who were not enthusiastic about helping visitors during their stay at the destination, decreased visitors' satisfaction and possibility to get to know the destination better (Zhang and Chow, 2004). Guides who are energetic and show that they enjoy doing their job, can arouse visitors' interest in the presented topic, create pleasant memories and serve as a role model for sustainable behavior after the tour ends. It is shown that passionate employee can increase customers' loyalty (Hapsari et al., 2017) and be a moderator for ethical leadership and behavior (Ogunfowora, 2014).

Importance of guide's knowledge and telling stories in an engaging and interesting way were shown through their ability to act as predictors for almost all learning outcomes - storytelling for enjoyment/satisfaction and actions, while using of knowledge for interest and motivation to learn, action orientation and actions. It is shown that knowledge and the way it is presented can have central role in environmental education of visitors and their future actions. During the tour, guides should avoid a simple enumeration of facts, use of too professional terms (e.g. Latin names for certain species) without adequate explanation since it can remind visitors on school classes and decrease the level of enjoyment, while leaving the feeling of boring activity (Rubino et al., 2015).

An adequate and sufficient knowledge can build the interest of the visitors, encourage them to ask questions and actively participate in the tour by giving their own interpretations (Foreman-Peck and Travers, 2013). The only learning outcome that had lower percentage of variance 
was "action orientation". This lower percentage can be explained by putting skills in this group and skills require longer period in order to be developed. It cannot be expected that during a tour that lasts one hour visitors learn and develop some new skills, but it can be a good start.

The results showed that if national parks want to encourage visitors' sustainable behavior and leave national parks with moti vation to learn, gain some new knowledge and skills, they need to have one thing in mind - visitors do not want to be passive and silent observers, they want to actively participate in the tour. This can be achieved by asking questions, stimulate visitors to carefully look and by using some learning activities. During the tour, guides should avoid talking all the time, since it can be monotonous for visitors, but rather give space to visitors by asking questions. Asking questions can activate visitors' knowledge, give them opportunity to hear what other visitors think, to hear their perspectives, give opportunity to think out loud, to interpret and use imagination.

As Kember (2009) stated in his research, professors who used interaction with students as one of the teaching methods, encouraged students to much easier express their opinion and gain some skills like how to solve a problem or make a decision. The factors which usually motive people to visit national parks include the possibility to see different animal and plant species, opportunitie s to learn more about nature, or opportunity to enjoy in a beautiful landscape and peaceful/quiet environment (Gundersen et al., 2015; Mutanga et al., 2017). This shows that visitors want during the tour to see or hear some things in person, not just to imagine based on a gui de's story. The guide can draw attention to a particular species when the group is near them and allow visitors to carefully look at them or if it is not possible to show them in a picture or video. During or after the tour, guides can use some learning activities to encourage action orientations among visitors, like guessing which species are presented based on the cards with pictures, divide visitors in groups to apply appropriate components of survival for humans, plant and animal species, give case studies, etc.

The results from this research can be a useful guideline for the management of the national parks and other protected natural areas. During the training or hiring new employees, special focus should be paid to the competencies that will enhance learning outcomes and sustainable behavior of visitors. The focus should be especially put on knowledge (land management, ecological processes and environmental practices and issues) and those competencies that will let visitors to actively be involved in the tour and interpret their own views. Future research can analyze if other factors like motives for visiting the national park, visitors' demographic characteristics, type of the tour, differences between expectations and guide's performances can shape sustainable behavior and learning outcomes on a different way.

\section{REFERENCES}

Al Jahwari, D.S., Sirakaya-Turk, E., \& Altintas, V. (2016). Evaluating communication competency of tour guides using a modified importance-performance analysis (MIPA). International Journal of Contemporary Hospitality Management, 28(1), 195-218. doi: 10.1108/IJCHM-02-2014-0064

Armstrong, E., \& Weiler, B. (2002). Getting the message across: An analysis of messages delivered by tour operators in protected areas. Journal of Ecotourism, 1(2\&3), 104-121. doi: 10.1080/14724040208668118

Black, R., \& Crabtree, A. (2007). Stakeholders' perspectives on quality in ecotourism. In Ecotourism series, number 5, Quality assurance and certification in ecotourism (pp. 136-146). CABI Publishing, London.

Boren, L.J., Gemmell, N., \& Barton, K. (2009). The role and presence of a guide: preliminary findings from swim with seal programs and land-based seal viewing in New Zealand. Tourism in Marine Environments, 5(2-3), 187-199. doi: 10.3727/154427308787716776

Brown, T.J., Ham, S.H., \& Hughes, M. (2010). Picking up litter: an application of theory-based communication to influence tourist behavior in protected areas. Journal of Sustainable Tourism, 18(7), 879-900. doi: 10.1080/09669581003721281

Bryon, J. (2012). Tour guides as storytellers - from selling to sharing. Scandinavian Journal of Hospitality and Tourism, 12(1), 27-43. doi: $10.1080 / 15022250.2012 .656922$

Coolican, H. (2004). Research methods and statistics in psychology, Routledge, Abingdon, United Kingdom.

Ćurčić, N.B., Milinčić, U.V., Stranjančević, A., \& Milinčić, M.A. (2019). Can winter tourism be truly sustainable in natural protected areas? Journal of the Geographical Institute "Jovan Cvijić” SASA, 69(3), 241-252. doi: 10.2298/IJGI1903241C

Curtin, S. (2010). Managing the wildlife tourism experience: The importance of tour leaders. International Journal of Tourism Research, 12, 219-236. doi: $10.1002 /$ jtr.747

Dong, L.C., Droege, S.B., \& Johnson, N.B. (2002). Incentives and self-interest: Balancing revenue and rewards in China's tourism industry. Tourism and Hospitality Research, 4, 69-77. doi: 10.1177/146735840200400106

Etelapelto, A., \& Lahti, J. (2008). The resources and obstacles of creative collaboration in a long-term learning community. Thinking Skills and Creativity, 3(3), 226-240. doi: 10.1016/j.tsc.2008.09.003

Foreman-Peck, L., \& Travers, K. (2013). What is distinctive about museum pedagogy and how can museums best support learning in schools? An action research inquiry into the practice of three regional museums. Educational Action Research, 21(1), 28-41. doi: 10.1080/09650792.2013.761924

Gundersen, V., Mehmetoglu, M., Vistad, O., \& Andersen, O. (2015). Linking visitor motivation with attitude towards management restrictions on use in a national park. Journal of Outdoor Recreation and Tourism, 9, 77-86. doi: 10.1016/j.jort.2015.04.004

Haig, I., \& McIntyre, N. (2002). Viewing nature: The role of the guide and the advantages of participating in commercial ecotourism. Journal of Tourism Studies, 13(1), 39-47.

Hamalainen, R., \& Vahasantanen, K. (2011). Theoretical and pedagogical perspectives on orchestrating creativity and collaborative learning. Educational Research Review, 6(3), 169-184. doi: 10.1016/j.edurev.2011.08.001

Hansen, A.H., \& Mossberg, L. (2017). Tour guides' performance and tourists' immersion: facilitating consumer immersion by performing a guide plus role. Scandinavian Journal of Hospitality and Tourism, 17(3), 1-20. doi: 10.1080/15022250.2016.1162347

Hapsari, R., Clemes, M.D., \& Dean, D. (2017). The impact of service quality, customer engagement and selected marketing constructs on airline passenger loyalty. International Journal of Quality and Service Sciences, 9(1), 21-40. doi: 10.1108/IJQSS-07-2016-0048

$\mathrm{Hu}$, W., \& Wall, G. (2012). Interpretative guiding and sustainable development: A framework. Tourism Management Perspectives, 4, 80-85. doi: 10.1016/j.tmp.2012.05.003

Hwang, J., \& Lee, J.J. (2019). Understanding customer-customer rapport in a senior group package context. International Journal of Contemporary Hospitality Management, 31(5), 2187-2204. doi: 10.1108/IJCHM-02-2018-0128

Kember, D. (2009). Promoting student-centered forms of learning across an entire university. Higher Education, 58, 1-13. doi: 10.1007/s10734-008-9177-6

Koroglu, O., \& Guzel, O. (2013). Visitor perceptions of the role of tour guides in natural resource management and sustainable tourism. Romanian Economic Business Review, 8(4.1), 69-80.

Kuo, N.T., Cheng, Y.S., Chang, K.C., \& Chuang, L.Y. (2018). The asymmetric effect of tour guide service quality on tourist satisfaction. Journal of Quality Assurance in Hospitality \& Tourism, 19(4), 521-542. doi: 10.1080/1528008X.2018.1483283

Marion, J.L., \& Reid, S.E. (2007). Minimizing visitor impacts to protected areas: The efficacy of low impact education programmes. Journal of Sustainable Tourism, 15(1), 5-27. doi: 10.2167/jost593.0 
Matsushima, H. (2007). Effects of using interpretation method in regard to public beach management at Ishikari Coast, Hokkaido. Landscape Research Japan, $70(5), 523-526$.

Mossberg, L. (2003). A marketing approach to the tourist experience. Scandinavian Journal of Hospitality and Tourism. 1(7), 59-74. doi: $10.1080 / 15022250701231915$

Mutanga, C.N., Vengesayi, S., Chikuta, O., Muboko, N., \& Gandiwa, E. (2017). Travel motivation and tourist satisfaction with wildlife tourism experiences in Gonarezhou and Matusadona National Parks, Zimbabwe. Journal of Outdoor Recreation and Tourism, 20, 1-18. doi: 10.1016/j.jort.2017.08.001

Ogunfowora, B. (2014). It's all a matter of consensus: Leader role modeling strength as a moderator of the links between ethical leadership and employee outcomes. Human Relations, 67(12), 1467-1490. doi: 10.1177/0018726714521646

Pereira, E.M., \& Mykletun, R.J. (2012). Guides as contributors to sustainable tourism? A case study from the Amazon. Scandinavian Journal of Hospitality and Tourism, 12(1), 74-94. doi: 10.1080/15022250.2012.663558

Pereira, A. M. (2015). Tour guides and destination image: Evidence from Portugal. Journal of Tourism and Hospitality Management, 3(7-8), 129-150. doi: $10.17265 / 2328-2169 / 2015.08 .001$

Powell, R.B., Stern, M.J., \& Frensley, B.T. (2020). Identifying outcomes for environmental education at national parks. In America's Largest Classroom: What We Learn from Our National Parks (pp. 245-259). University of California Press, Oakland.

Rubino, I., Barberis, C., Xhembulla, J., \& Malnati, G. (2015). Integrating a location-based mobile game in the museum visit: Evaluating visitors' behaviour and learning. Journal of Computing and Cultural Heritage, 8(3), 1-18. doi: 10.1145/2724723

Schep, M., Van Boxtel, C., \& Noordegraaf, J. (2017). Competent museum guides: defining competencies for use in art and history museums. Museum Management and Curatorship, 33(1), 2-24. doi: 10.1080/09647775.2017.1387590

Siew, K.M., Ramachandran, S., Siow, M.L., Shuib, A., \& Kunasekaran, P. (2018). Visitors' level of awareness on safety instructions at Giant Panda Conservation Centre (GPCC), Zoo Negara, Malaysia. International Journal of Business and Society, 19(1), 103-116.

Tatar, C.F., Herman, G.V., \& Gozner, M. (2018). Tourist guides' contribution to sustainability in Romania. GeoJournal of Tourism and Geosites, 1(21), 282287. doi: $10.30892 / \mathrm{gtg} .21122-287$

Tsai, C.Y., Wang, M.T., \& Tseng, H.T. (2016). The impact of tour guides' physical attractiveness, sense of humor, and seniority on guide attention and efficiency. Journal of Travel \& Tourism Marketing, 33(6), 824-836. doi: 10.1080/10548408.2015.1068264

Weiler, B., \& Walker, K. (2014). Enhancing the visitor experience: Reconceptualising the tour guide's communicative role. Journal of Hospitality and Tourism Management, 21, 90-99. doi: 10.1016/j.jhtm.2014.08.001

Weiler, B., \& Yu, X. (2007). Dimensions of cultural mediation in guiding Chinese tour groups: Implications for interpretation. Tourism Recreation Research, 32(3), 13-22. doi: 10.1080/02508281.2007.11081535

Wiles, R., \& Hall, T.E. (2005). Can interpretive messages change park visitors' views on wildland fire? Journal of Interpretation Research, 10(2), 18-35.

Wong, A. (2001). Satisfaction with local tour guides in Hong Kong. Pacific Tourism Review, 5, 59-67.

Yu, X., Weiler, B., \& Ham, S. (2002). Intercultural communication and mediation: A framework of analyzing intercultural competence of Chinese tour guides. Journal of Vacation Marketing, 8, 75-87. doi: 10.1177/135676670200800108

Zhang, H.Q., \& Chow, I. (2004). Application of importance-performance model in tour guides' performance: evidence from mainland Chinese outbound visitors in Hong Kong. Tourism Management, 25(1), 81-91. doi: 10.1016/S0261-5177(03)00064-5 